\title{
Sustainability Reporting as a Catalyst to Performance of Insurance Company in Nigeria
}

\author{
Owolabi, S.A. ${ }^{1}$, Okulenu, Samuel Adetayo ${ }^{2}$ \\ ${ }^{1,2}$ Department of Accounting, Babcock University, Nigeria \\ owolabis@ babcock.edu.ng, okulenu@gmail.com
}

\begin{abstract}
The paper explicated on sustainability reporting as a catalyst to performance of insurance company in Nigeria. The papermade use of the ex post facto research design. A sample was taken from Mutual Benefit Assurance PLC, which was employed in this paper. Data was gotten from the annual reports and accounts of the sampled firm through content analysis. The data were analyzed using multiple regression analysis. The results revealed that sustainability reporting has a small but positive relation with Environmental Reporting and market value and performance of the organization, social reporting was negatively related with market value and performance of the organization, and economic reporting was positively related with market value and performance of the organization. The study recommended that companies should intensify sustainability reporting as this could lead to increased market performance and that of local environments where these firmsfunction and other key players like employees and social and environmental non-governmental organizations must require sustainability reporting to satisfy their information needs and assist them to hold firms to account for not only economic performance but also environmental and social performance as its impacts them.
\end{abstract}

KEYWORDS: Sustainability Reporting, Environmental Reporting, Performance,

Introduction

Organizations, Economic Reporting

Human activities are currentlyregarded by some persons as having a negative impact on the society, economy and ecology which the generations of the future will experience (Unerman, Bebbington \&O'Dwyer 2007). We are now faced with a series of very tangible environmental and social crises. Response to these problems by leaders of business organizations help firms reduce risks, promote corporate brand and gain competitive edge while helping to mitigatepoor living standards and elevatethe quality of life of people in general. Firms are no longer prioritizing to the maximization of shareholders wealth alone but are embracing activities that tend to maximize the profits accruable to all the key players. Big companies once viewed upon as the exclusive concern of its owners are now seen as being answerable to the society also (Ekwueme, 2011). This to a larger extent equates to companies seen to beresponding positively towards issues centered aroundsustainability.

Sustainability reporting has become of huge relevance in accounting and reporting literature for the past thirty years. This is because stakeholders now need both financial and non-financial information to help them make informed decisions. 
Stakeholders such as investors and shareholders use this information to carry out investment and other business-related decisions. Utile, Zayol and Aondoakaa (2018) opine that there is a global need for sustainability reporting probably because it will help reduce restiveness among stakeholders and create business friendly environment. The usefulness of sustainability reporting is more when the market reacts to such information disclosure. This information should inform managers' decisions as to the right ways of channeling their funds. Sustainability reporting (a term used to describe a company's reporting on its social, economic and environmental performance) is expected to increase sales volume, increase profitability, enhance customer satisfaction and above all, provide an opportunity for managers to weigh their investment options.

There are many definitions of sustainability reporting. However, this paper adopts the definition by Elkington (1997) "the term sustainability reporting or "triple bottomline" is a yardstick for measuring and reporting corporate performance against social, economic, and environmental parameters.It is also the whole set of values, issues, and processes that companies must address in order to minimize any problemresulting from their activities and to create economic, social and environmental values and the three lines represent society, economy and the environments." A sustainability report depicts the organization's values and governance model and demonstrates the link between its strategy and its commitment to a sustainable global economy. Sustainability reporting can help organizations to measure, understand and communicate their economic, environmental, social and governance performance, and then set goals, and manage change more impactfully.

Sustainability often described as the intersection of three sectors: economic, social and environmental is seenas an important practice for the modern business firmsto thrive. Ballon, Heitger and Landes (2009) posits that organizations have over the time discovered that meeting key players' expectations is a prerequisitefor sustainability and therefore required to achieve overall strategic businessgoal. Most companies across the world are embracing Sustainability principles as well as reporting practices. The Central Bank of Nigeria (CBN) has since 2012 issued Sustainability principles to be adhered to by Deposit Money Banks (DMBs). Efforts in this area were further enhanced by the Nigerian Stock Exchange (NSE) in 2016 with its sustainability reporting requirements.

\section{Statement of the Problem}

Sustainability reporting has gradually gained relevance not in Nigeria alone but also the world over. This is in response to the request for organizations to be more accountablein how they handle their economic, social and environmental activities as 
they affect key actors. It is also widely known in the business sector and most academic literature on sustainability reporting that this reporting system is advantageous. However, many studies on sustainability reporting has reported on the impact of sustainability reporting on profitability. These studies have largely connected sustainability reporting to backward-looking firm profitability, that is accounting based returns, rather than forward-looking market value or stock returns. With an unclear nexus between sustainability reporting and market value may be due, in part to the omission in some studies of control variables such as firm size and leverage hence the need for more studies to be carried out in this area especially in the Nigerian Insurance sector. It is in this light that this research examined sustainability reporting as a catalyst to performance of insurance company in Nigeria.

\section{General Objective}

The aim of this paper is to examine sustainability reporting as a catalyst to performance of insurance company in Nigeria.

\section{Specific Objectives}

i. To examine the relationship betweensustainability reporting and the performanceof an insurance company.

ii. To determine the extent to which sustainability reporting, environmental, social, and Economic Reporting will cause variations in the performance of an insurance company

iii. To evaluate the influence of sustainability reporting in determining organizational market value of an insurance company.

\section{Research Questions}

i. To what extent does sustainability reporting related to the performance of an insurance company?

ii. To what extent does sustainability reporting, environmental, social and economic reporting cause variation in the performance of an insurance company?

iii. To what extent does sustainability reporting influencethe organizational market value of an insurance company?

\section{Review of Related Literature}

\section{Concept of Sustainability Reporting}

Sustainability Reporting, also described as social accounting and environmental accounting, corporate social reporting, corporate social responsibility reporting, triple bottom line accounting or non-financial reporting originated about four decades ago 
(Asaolu, Agboola, Ayoola\&Salawu, 2011). However, there is no single, generally accepted definition of Sustainability reporting. It is a term broadly used to define a company's reporting on its economic, environmental and social performance(KPMG, 2008).

The Global Reporting Initiative (GRI)'s Sustainability Reporting Guidelines cover three linked elements of sustainability pertinent to organizations (GRI, 2011) as follows: Economic: includes benefits andwages, labour productivity, creation of jobs, expenditures on research and development as well asinvestments in training and other forms of human capital. The economic element includes, but is not limited to, financial information. Environmental: including, for example, impacts of processes, products and services on land, air, water, biodiversity and human health. Social: including, for example, workplace safety and health, retention of employees, labour rights, human rights, wages and working conditions at outsourced operations.

\section{Benefits of Sustainability reporting}

\section{Internal benefits for companies and organizations include:}

- Increasedcomprehensionof risks and opportunities

- Underscoring the nexus between financial and non-financial performance

- Influencing long-term management policy and strategy, and business projections

- Streamlining processes, cutting expenses and increasing efficiency

- Benchmarking and assessing sustainability performance as it relatesto laws, codes,performance standards, norms, and voluntary initiatives

- Avoiding being involved in publicized environmental, governance and social failures

- Conducting a comparison of performance internally, and between organizations and sectors

\section{External benefits of sustainability reporting include:}

- Maintains trust: Openness between businesses and key actors, as it relatesto nonfinancial performance, aids an organization in its search to elicitrecommendations from customers while mitigating risks. Sustainability reporting, hence, maintains the image of a brand and the reputation of a firm.

- Helps in improvement of the process and the whole system: By x-raying the issues such as material used, energy consumption, waste producedand scrutinizing internal management and decision-making processes, cost of runningthe company can be cut. Sustainability reporting alsorequires a firm to present its plans on how it can implement changes with the aid of sustainable development.

- Enhancing decision-making strength: Sustainability is away of creatinginnovations for companies which will help themattaincompetitiveedge in the market. It helps the respective firms to look after the risks and surmount them. 
Itprovides firms with different opportunities that can help them begin new activities, thereby breaking the limits to enteringin new markets and attract investors.

- Building strategies for improvement: Detailed analysis of strengths and weaknesses with the aid of sustainability report presents a greater picture and makes firmsattempt to address weaknesses and regulate mechanisms for holistic development. Additionally, interfacing with key players can make the firms to have broad-ranging visions. Therefore, sustainability can be made a cardinalpart of the establishment for stating a strong name in the market. It enables the customers or other key actors to understand the peculiar values of the organization inboth the tangible and intangible forms. It enables a firmto work on long-term beneficial policies, strategiesandplans.

- Reduce Compliance Cost: Scrutinizing sustainability report helpsfirms in their data gatheringthat is cost-effective, regulate requirements, and avoid lapses while enablingfirmsto address issues in effective and efficient manner.

\section{Corporate Performance}

Corporate performance is a yardstick for measuring how an organization can satisfy the owners typically by way of profit maximization or shareholders wealth; it also expresses a measure of both financial and non-financial performance by way of satisfying all the stakeholders of the firm. It has been argued that firms that have implemented sustainability accounting may underperform because they are liable to high expenses as a result of high labour cost. They also give up many cash cow and lucrative businesses because these businesses do not fit properly with the norms of the society of localization (e.g. engaging in businesses with adverse environmental consequences) in other words high sustainability organizations face tighter constraints on how they can carry out their businesses because sustainability accounting introduces more constraints which may consequently result to low productivity by the organization. However, an opposing view is that firms in the high sustainability group are capable of better performance because they acquire quality labour, establish a good supply chain and most importantly they maintain a good relationship with the society where the organization is domicile, this reduces conflict between the organization and the society and call for a peaceful work environment (Mitchell 1997). It is also believed that because of the constraints faced by these organizations, they engage into diversified business opportunities to enable them to compete favorably with their counterparts.

\section{Theoretical Framework}

\section{The Stakeholder's Theory}


The stakeholder theory can be employed theoretically to explain sustainability. The position upheld by the stakeholder's theory is that all key players are entitled to beingtreated fairly by the establishment. Freeman (1984) defined a stakeholder as any group or individual who can eitheraffect or is affected by the achievement of the organization's objectives. These groups or individuals may include employees, competitors, customers, suppliers, governments, banks, investors, non-governmental organizations (NGOs), and may also include the societyat large. The focus of the stakeholder's theory is to determine which key players are more relevant to the organization, this is very crucial to the management of the organization because it is believed that the success of the organization in terms of performance is hingedupon the support of the stakeholders (Belinda 2015).

The stakeholder's theory is divided into the ethical and managerial aspects; the latter is concerned with identifying the most important amongst the stakeholders to satisfy their desires (Adekanmi 2015). To this aspect of stakeholder's theory, not all stakeholders in their nature can affect the productivity or performance of an organization. This implies that more attention needs to be given to the more influential stakeholders such that the influence of the stakeholders is ranked in such a way that more efforts are made to keep a strong relationship with powerful stakeholders. Conversely,the ethical aspect of the stakeholder's theory posits that all key actors have earnedthe right to obtain adequate and equal treatment by the organization and that the issue of higher influence of some stakeholders on the organization is not relevant; it has been debated that the influence of the organization on a key player is what should be prioritized in this case rather than the economic importance of some stakeholders to the establishment. Within the ethical right purviewof the theory, all stakeholders are entitledto certain benefits like employment and other social benefits. They also deserve the right to be provided with information on the performance of the organization and its impact on their society which calls for sustainability reporting.

\section{The Legitimacy Theory}

Organizations exist within a society; such establishments are morally tied by the practices of such societies, but legitimacy refers to conformityto the law or rule of the land (Ayong, 2001). The logic behind the legitimacy theory is that, firms are involved in a social contract agreement between them and the society within which they are situated. These norms are not fixed they change with time thus it is expected that the organization should respect the ethics and moral of the society.

It is believed that by this contract, the society has the right to revoke the contract of the organization if the organization operates contrary to the ethics of the society. It is also believed that the organization owe the society explanations in cases where they seem to deviate from normal to abnormal. Whenever an organization cannot give 
explanation for its operations, then in a sense the community may retract its contract from continuing its operations with the organization. It is therefore, imperative that companies adapt to changes in the society as the community's expectations also change over time (Mansell 2013).

\section{The Agency Theory}

It is believed in theory that shareholders are the only owners of the firm, and the task of its directors is merely to ensure that shareholder's interests are protected and maximized. More precisely, the onus of the directors is to run the company in a way that would maximize the long run returns to its owners and thus maximize the company's profit and cash flows (Shoaib, 2011). The agency theory presents a description of the agency relationship between the managers of the company and its key actors especially with regards to the provision of financial and non-financial information (Reiner, 2008). It has been argued that managers tend to provide information to the owners of the firm in a way that would favour their aspirations even though the maximization of shareholder's wealth and company profit are the key objectives of finance and are supposed to be keen to managers. Miles (2012) observed that managers do not always run the firms they work for to maximize shareholder's wealth, they seem not to align their interests with those of their principals, for this reason the development of the agency theory took into account the principal-agency relationship as a yardstickforascertaining theperformance of firms (Belkaoui\&Karpik, 1990). Also, managers may like to report their information in such a way that would differentiate them from the poorly managed corporations the information provided by the managers is used by all stakeholders of the business including the society this calls for a comprehensive corporate social reporting by the management. Another problem that is associated with the agency theory is that it is concerned mainly with the financial stakeholders (shareholders and creditors) and disregard the need of other parties such as employees and the general public who are also interested in the performance of the firm but have no formal contractual relationship with the firm though their actions may affect the firm indirectly.

\section{Empirical Framework}

Asaolu (2011) x-rayedsustainability reporting in the Nigerian Oil and Gas sector using six major Oil and Gas multinational companies operating in Nigeria. The study adopted Content analysis method of analyzing data that was gotten from annual reports of selected oil and Gas companies to ascertain the degree to which their report conforms to best practices. Findings showed that sustainability performance indicators were not found in any of the establishments sampled. Asaolu used content analyses to analyze his data; however, content analyses are descriptive in nature. It describes what is there but may not disclose the fundamental reason for the observed trend. It tells us 
what happened but not the reason why it happened also, observed trend may not be a correct measure of reality.

Oyewo (2014) researched on sustainable development reporting practices by Nigerian Banks using publicly quoted commercial banks in Nigeria as his population. He sampled the banks based on the existence of a standalone report on sustainability reporting in the year 2012 annual report. Twelve (12) banks were selected for content analysis; correlation analysis was used to examine the connection between variables. ANOVA was used to test for mean difference. Findings of thisresearchrevealed that sustainable development reporting is not dependent on size or on the extent to which organizations make profit. In addition, it was observed that despite the large sizes of banks their sustainability development is not appreciable. The limitation of this research design is in the use of correlation analyses as correlation only tells us of the relationship without informing us on what caused the relationship.

Beredugo (2012) studied the nexus between environmental accounting and reporting and sustainable development in Nigeria. The researcher employed the survey research design. Data was gathered fromfour hundredparticipants from a population of three million participants. Pearson's correlation coefficient, student t-test and the ordinary least square methods were used for analyzing data. Findings showed that there is a positive relationship between environmental accounting and reporting,and sustainable development and that there existresults ofnon-compliance. He also found that key actors increasingly expectfirms to manufacture goods efficiently and at reasonablycompetitive prices without causing harmto the environment.

Norhasimah (2015) examined the impact of environmental disclosure on financial performance in Malaysia using the Malaysian public limited companies. Nonprobabilistic sampling (purposive sampling) was used to arrive at a sample of hundred firms of market capitalization for 2011. Norhasimah selected these companies because they were established and expected to have more activities that influence society as depicted in their financial statements. Data was gathered from financial reports of these firms for the year 2011. An environmental index was generated, 10\% of the total sample was selected to conduct a pilot test of ten (10) companies. ROA, EPS and ROE were used to assess performance. To test the hypotheses, spearman's correlation and multiple regressions were employed. Findings showed that there is a significant association between total environmental disclosure and profit margin. Norhasimah used purposive sampling method to derive a sample of 100 companies but purposive sampling is a judgmental form of sampling which is associated with a form of bias selection which does not give other companies that may have altered the result equal chances of being selected. 
Alshehhi, Nobanee and Khare (2018) provided an analysis of the literature concerning the impact of corporate sustainability on corporate financial performance. They used content analysis to examine the literature and establish the current state of research. A total of 132 articles from top-tier journals were shortlisted. They found that $78 \%$ of publications report a positive relationship between corporate sustainability and financial performance. Variations in research methodology and measurement of variables led to the divergingviews on this relationship.

Ndukwe and Nwakanma (2018) studied the relationship between corporate sustainability reporting and profitability of selected quoted companies in Nigeria. The study employed ex post facto research design. Data used for the study were sourced from annual reports and financial statements of the companies for the period 2011 to 2015. Multiple regression analysis technique was used to test the hypotheses. Findings showed a negative relationship between return on equity and corporate sustainability reporting. No significant relationship was showed between earnings per share and corporate sustainability reporting.

\section{Methodology}

This paper adopted a descriptive type of ex-post facto research design which was undertaken after the events hadtaken place and the data were already existing. A sample was taken from Mutual Benefit Assurance Plc was used for the study. Data was obtained from the annual reports and accounts of these sampled firms through content analysis. Multiple regression analysis was applied to examine the impact of sustainability reporting as a catalyst for performance.

The multiple regression model was built as follows:

$\mathrm{TQ}=\beta_{0}+\beta_{1} \mathrm{ENV}_{\text {it }}+\beta_{2} \mathrm{SOC}_{\mathrm{it}}+\beta_{3} \mathrm{ECO}_{\text {it }}+\beta_{4} \mathrm{SIZE}_{\text {it }}-\beta_{5} \mathrm{LEV}_{\text {it }}+\mathrm{e}$

Where, $\mathrm{TQ}=$ Tobin's $\mathrm{Q}$

$\mathrm{ENV}=$ Environmental reporting

SOC $=$ Social reporting

$\mathrm{ECO}=$ Economic reporting

SIZE $=$ Logarithm of total revenue

LEV $=$ Leverage

$\mathrm{B}_{0}=$ the constant;

$B_{1} \beta_{2}, \beta_{3}, \beta_{4}=$ the regression coefficients;

$\mathrm{e}=$ the error term used in the regression model. 


\section{Results and Findings}

The result of the study is presented thus:

Regression result of sustainability reporting and Tobins $\mathbf{Q}$

\begin{tabular}{|l|l|l|l|l|}
\hline $\mathrm{R} .261$ & $\mathrm{R} .261$ & & & \\
\hline $\mathrm{R}^{2} .068$ & $\mathrm{R} .068$ & & & \\
\hline $\mathrm{R}^{2}$ adj .053 & $\mathrm{R}$ adj .053 & & & \\
\hline P-value .000 & P-value .000 & & & \\
\hline Variable & Coefficient & t-value & P-value & VIF \\
\hline Constant & 8.868 & 2.520 & .012 & \\
\hline ENV & 1.422 & 1.539 & .125 & 1.441 \\
\hline ECO & .818 & .818 & .480 & 1.407 \\
\hline SOC & -3.208 & -2.788 & .006 & 1.316 \\
\hline SIZE & -.272 & -3.772 & .000 & 1.041 \\
\hline LEV & 1.188 & 1.785 & .075 & 1.017 \\
\hline
\end{tabular}

\section{Source: SPSS}

From table 4.1, there is a weak relationship between sustainability variables and performance (Tobins Q) at a value of $26.1 \%$. It also indicates that sustainability reporting accounts for only $6.8 \%$ of variations in Tobins $\mathrm{Q}$ while $93.2 \%$ is accounted by factors outside this study. The difference between $\mathrm{R}^{2}$ and $\mathrm{R}^{2}$ adjusted is $1.5 \%(6.8 \%-5.3 \%)$ and shows that the result is a true reflection of the population from which the sample was drawn. The table also indicates that a unit increase in environmental and economic reporting will insignificantly increase Tobins $\mathrm{Q}$ by $1.42 \%$ and $0.82 \%$ respectively while a unit in social reporting will significantly reduce Tobins Q by $3.20 \%$. Also, a unit increase in SIZE will significantly decrease Tobins $Q$ by $0.27 \%$ and an increase in leverage by 1 unit will insignificantly increase Tobins $\mathrm{Q}$ by $1.19 \%$. This means that environmental and economic reporting quality insignificantly increases Tobins $Q$ while social reporting significantly reduces Tobins Q.

In summary, this study found that:

A weak relationship exists between sustainability reporting and the performance of an insurance company. This is because the $\mathrm{R}$ and the adjusted $\mathrm{R}^{2}$ for the model present a weak line of fit at $\mathrm{R}=26.1 \%$ and adjusted $\mathrm{R}^{2}=0.68$ which indicates that sustainability reporting accounts for only $6.8 \%$ of variations in the performance of the insurance company under study.

It was also evident in the result of the study that sustainability reporting, environmental, social and economic reporting causes variation in the performance of an insurance company. The Table indicates that a unit increase in environmental 
and economic reporting will insignificantly increase the performance of insurance company by $1.42 \%$ and $0.82 \%$ respectively while a unit increase in social reporting will significantly reduce the performance of the insurance company by $3.20 \%$. Also, a unit increase in SIZE will significantly decrease the performance of insurance company by $0.27 \%$ and an increase in leverage by 1 unit will insignificantly increase the performance of insurance company by $1.19 \%$. From afore mentioned findings it is evidenced that sustainability reporting influences the organizational market value of an insurance company.

\section{Discussion of Findings}

The findings of this study are far reaching as it reliably presents the situation with respect to sustainability reporting in the insurance company. Contrary to findings by Asaolu (2011) that there are no sustainability reporting indicators in the oil and gas multinational companies; the present study observed the presence of multinational indicators in the insurance company under study. The indicators were subjected to relevant statistical analysis and results show that these indicators do relate with the performance of an insurance company.

The finding that sustainability reporting do have a relationship though not strong contradicts the finding of Oyewo (2014) that sustainability reporting do not have any relationship with the size and profit of firms. In factOyewo (2014) indicated that there is no appreciable growth in sustainability reporting in the firms he studied. The study is also slightly different from Beregudo (2012) and Norhasimech (2015) who found significant positive relationship between sustainability reporting and development in firms in that the relationship found in our case is weak and insignificant.

\section{Conclusion}

In conclusion, this study ascertained that sustainability indicators are found in the insurance company under study and that these indicators do have weak relationship with the performance of the insurance company.

Furthermore, this study revealedthat an increase in sustainability/environmental reporting leads to improvedmarket performance, though not significant. It is observed that economic reporting has a positive impact on market value of insurance company and should be encouraged.

In addition to this, it was observed that social reporting is not relevant as statistics have shown that it is capable of decreasing market performance and therefore should be discouraged. 
Finally, sustainability reporting is not a major determinant of market performance. This is because it is weakly correlated with market performance and is also found to be insignificant statistically.

\section{Recommendation}

From the findings of this study it is recommended that:

1. Policy makers should consider the inclusion of sustainability reporting variables in the accounting framework of firms to improve transparency and accountability.

2. Investors should consider the sustainability indicators of a firm before taking decisions on which firms to invest in.

3. The study proposed that companies should intensify sustainability/ environmental reporting as this could lead to increased market performance.

4. Host communities, non-governmental organizations and other stakeholders must demand sustainability reporting to address their information needs and help them hold companies accountable for not only economic performance but also environmental and social performance as its affect themrespectively.

5. In addition, sustainability reporting ought tobe perceived as a tool that can be applied to dynamize the interaction between investors and businesses and its communities of operation. There is a connection between good environmental, social and governance performance and the enablement of the organizations and companies to be profitable and wiggle throughharshperiods. Therefore, sustainability reporting should be regarded as internal monitoring and external communication which will enable companies satisfy the increasing information demands and reflect transparency in its accountability to their various stakeholders.

\section{Suggestion for Further Studies}

1. Future research should expand on the scope of the study to include a meta-analysis of insurance companies' performance with respect to sustainability reporting.

2. Future study should investigate factors that can improve the significance of sustainability reporting in determining the market and stock value of insurance companies. 


\section{References}

Adekanmi, A. D. (2015). Environmental accounting: A tool for sustainable development. International Journal of Advanced Academic Research, 1(2).

Asaolu T. O., Agboola A. A., Ayoola T. J., \&Salawu M. K. (2011), Sustainability Reporting in the Nigerian Oil and Gas Sector. Proceedings of the Environmental Management Conference, Federal University of Agriculture, Abeokuta, Nigeria. Pp 1-24

Ballou, B., Heitger, D.L., \&Landes, C.L. (2009). The Future of Corporate Sustainability Reporting: A Rapidly Growing Assurance Opportunity

Belkaoui, A., \&Karpik, P. G. (1989).Determinants of the corporate decision to disclose social information.Accounting, Auditing and Accountability Journal, 2(1), 36-51.

Beredugo, S. B., \&Mefor, I. P. (2012).The Impact of environmental accounting and reporting on sustainable development in Nigeria. Research Journal of Finance and Accounting, 3(7)

Ekwueme, C. (2011) Social responsibility accounting: An overview, in M.A. Mainoma (Ed.) Contemporary issues in accounting development (PP. 45 63), A publication of the Association of National Accountants of Nigeria (ANAN) MCPD 2011.

Elkington, J. (1997). Cannibals with Forks: The Triple Bottom Line of 21st Century Business, Oxford: Capstone Publishing, Oxford, UK.

Freeman, R.E. (1984). Strategic Management: A Stakeholder Approach. Boston: M.A. Pitman

Global Reporting Initiative (2011). GRI Sustainability Reporting Guidelines version 3.1.https://www.globalreporting.org/.../G3.1-Guidelines-Incl-TechnicalProtocol.pdf

KPMG (2008). KPMG international survey of corporate responsibility reporting 2008. Retrieved from http://www.kpmg.com/SiteCollection Documents/ International-corporateresponsibility-survey-2008_v2.pdf. 
Mansell, S. (2013). Capitalism, corporations and the social contract: A critique of stakeholder theory. Cambridge: Cambridge University Press

Miles, S. (2012). Stakeholders: Essentially contested or just confused? Journal of Business Ethics 108(3): 285-298.

Mitchell, R.K., Agle, B.R., \& Wood, D.J. (1997). Toward a theory of stakeholder identification and salience: Defining the principle

Ndukwe E.O. D. \&Nwakanma G. N. (2018). Corporate sustainability reporting and firm profitability: A survey of selected quoted companies in Nigeria. The Nigerian Accountant, 51(2), 18 - 26.

Norhasimah, M. N., Norhabibi, A. S. B., Nor, A. A ., Sheh, M., Qamarul, A. S. K. \& Inaliah, M. A. (2015). The effect of environmental disclosure on financial performance in Malaysia 7th International Economics \& Business Management Conference, 5th - 6th October 2015.

Oyewo, B. M. (2014). Sustainable development reporting practices by Nigerian Banks. Mediterranean Journal of Social Sciences, 5

Reiner Quick (2008) Voluntary sustainability reporting practices in Germany: a study on reporting quality Journal of Social Technologies vol. 12, 2(2), p. 273-289

Shoaib, M. M. (2011). Impact of sustainability reporting on firm's performance: Evidence from Pakistan. African Journal of Business Management. 17(5), 56101.

Unerman, J., Bebbington, J., and O'Dwyer, B. (Eds.). (2007) Sustainability Accounting and Accountability, London: Routledge.

Utile, B. J., Zayol, P.I. \&Aondoakaa, E.K. (2018). Corporate sustainability reporting and the financial performance of the Nigerian listed industrial goods firms. The Certified National Accountant, 26 (3),45-51. 